\title{
Knowledge and Perception about Risk Factors and Symptoms of Cervical Cancer in Female Teachers of Government and Private Schools of Chandigarh
}

\author{
Aprajita Singla ${ }^{1}$, N K Goel ${ }^{2}$, Suman Mor $^{3}$, Meenu Kalia ${ }^{4}$ \\ ${ }^{1}$ MPH Student, Center for Public Health, ${ }^{3}$ Assistant Professor, Panjab University, Chandigarh, India \\ ${ }^{2}$ Head of Department, ${ }^{4}$ Assistant Professor, Community Medicine, Government Medical College \& Hospital, \\ Chandigarh, Chandigarh, India \\ Correspondence : Dr. Aprajita Singla, Email: aprasingla@gmail.com
}

\section{Abstract:}

Introduction: Cervical cancer ranks as the $2^{\text {nd }}$ most frequent cancer among women in India after Breast Cancer. School Teachers constitute important stakeholder position in the society. The knowledge about cancer cervix is beneficial for them and also to the children they teach. Objective: To assess and compare the knowledge about Cervical Cancer, its risk factors, symptoms and signs prevailing in Female School Teachers of Government \& Private Schools in the area of Chandigarh. Method: A Cross-sectional study using multistage random sampling was conducted among Female School Teachers. City was divided in to 4 quadrants, 1 private and 1 Government school was randomly selected from each quadrant. From each quadrant 50 participants were taken in the study. Interview of 202 teachers were conducted through predesigned and pretested questionnaire during February to April 2018. Results: Unawareness about risk factors for cervical cancer was found in $79 \%$ of respondents. On asking about risk factors for Cervical Cancer, $8 \%$ of participants mentioned that infertility, heredity, use of sanitary pads and depression leads to cervical cancer which shows myths prevailing in community. Awareness about signs and symptoms of Cervical Cancer was found only in 37\% respondents. Only 23.8\% of Government School Teachers and 37.6\% of Private School Teachers were aware about association of HPVwith Cervical Cancer. Conclusion: Low Levels of Awareness about Cervical Cancer was found in the study even in highly educated group of School Teachers belonging to Chandigarh.

Key words: Awareness, Cervix Cancer, Risk Factors, School Teachers

\section{Introduction:}

Cervical cancer ranks as the $2^{\text {nd }}$ most frequent cancer among women in India after Breast Cancer and is also the $2^{\text {nd }}$ most frequent cancer among women between 15 and 44 years of age after Breast Cancer. ${ }^{[1]}$ ICMR report in 2016 showed that Cancer of the cervix is the third most common cancer with estimated 1 lakh new cases in 2016 in India and about
1.04 lakh during 2020. It is estimated that every 8 minutes one woman dies of cervical cancer. ${ }^{[2]}$

Epidemiologic studies have shown that the Human Papilloma Virus (HPV) DNA was detected in $93 \%$ of the tumors of cervical cancer. ${ }^{[3]} \mathrm{HPV}$ is a necessary cause of cervical cancer, but it is not a sufficient cause. Other cofactors are necessary for progression from cervical HPV infection to cancer. As

\begin{tabular}{|l|l|l|}
\hline Quick Response Code & Access this article online & How to cite this article: \\
\hline Singla A, Goel N K, Mor S, Kalia M. Knowledge and \\
Perception about Risk Factors and Symptoms of \\
Cervical Cancer in Female Teachers of Government \\
and Private Schools of Chandigarh. Healthline. 2021; \\
12(1):70-75.
\end{tabular}


per previous studies, tobacco smoking, high parity, long-term hormonal contraceptive use, and coinfection with HIV have been identified as established cofactors. Co-infection with Chlamydia trachomatis and herpes simplex virus type-2, immunosuppression, and certain dietary deficiencies are other probable cofactors. ${ }^{[4]}$ There are many clinical characteristics that predispose a woman to cervical cancer: being sexually active in early age ,multiple sexual partners, delivery of the first baby before the age of 20 years, multiparty with poor birth spacing between pregnancies,poor socioeconomic status and poor personal hygiene. Carcinoma of the cervix shares similar epidemiological features to those of sexually transmitted diseases and viral infections and these are strongly linked to cancer cervix as causative agents. The awareness about risk factors can cause decrease in incidence of cervical cancer.

Women with Sexually Transmitted Disease (STD), HIV infection, herpes simplex virus 2 infection, HPV infection $(16,18,31,33)$ and condylomata have a high predisposition to cancer. Women who do not go for regular health check-ups and Pap tests, take combined Oral Contraceptive and Progestogens pills over 8-year periods are prone for adenocarcinoma of the endocervix (double the risk). Five per cent women exposed to diethylstilboestrol in utero developed carcinoma of vagina and cervix. ${ }^{[5]}$ Girls and women should be made aware about these facts which can contribute to lessen the burden of disease.

In 2013, according to PBCR Chandigarh Age Adjusted Incidence Rate of Cervix Uteri Cancer was 8.8. ${ }^{[6]}$ Seeing the high number of deaths and incidence of cervical cancer in Indian population it is necessary to make population aware about causes and symptoms of cancer of cervix.

As School Teachers are main stakeholders and influencer of the society, their knowledge will create awareness about cervical cancer among adolescent girls. Present study was conducted to assess and compare the knowledge about Cervical Cancer among female School Teachers of Government \& Private Schools in the area of Chandigarh.

\section{Method:}

A Cross-sectional study was conducted in randomly selected private and government schools of Chandigarh. The Study population included the Female School Teachers of selected Government and Private schools.There were 107 Government and 78 recognized private middle, secondary and senior secondary schools in Chandigarh. City was divided into four quadrants according to the directions according to map of the city. From each quadrant, a Government School and a Private School were selected randomly. From each quadrant, 25 Female Government Schools Teachers and 25 Female Private School teachers were selected. Equal representation was taken from Government Schools (101) and Private Schools of Chandigarh (101). consent was taken from teachers prior to data collection. Prior permission from the respective officials was taken to conduct the study. Study Period was four Months (January to April 2018).A Pre-designed and pre tested questionnaire was used to collect information for the study. Questionnaire was filled by the respondents themselves, without any assistance. Information was collected about socio-demographic information of study participants and knowledge was assessed about risk factors, symptoms and association of HPV with cervical cancer. The obtained data was entered into Microsoft Excel 2010. Descriptive Analysis was done in form of numbers, percentages, and represented in form of tables and figures. The data collected was analysed with help of MS Excel 2010.

\section{Results :}

Table 1 shows the age of respondents ranged from 25 to 60 years in Government Schools with mean of $42.29 \pm 9.089$ years and in Private Schools mean age was a $36.50 \pm 8.112$ yearwith range of 22-56 years. $83.2 \%$ of Government School teachers and $84.2 \%$ of Private schools were Postgraduate. 95\% offemale teachers of Government Schools and 73.3\% of Private Schools female teachers were married. Majority of respondents were having monthly income of Rs 30,000 to Rs 60,000 (46.5\% in Government and 
Table 1: Socio demographic distribution of the respondents

\begin{tabular}{|l|c|c|}
\hline Variables & Government(N=101) & Private(N=101) \\
\hline Mean Age & $42.29 \pm 9.089$ & $36.50 \pm 8.112$ \\
\hline Education & No.(Percent) & No.(Percent) \\
\hline Postgraduate & $84(83.2 \%)$ & $85(84.2 \%)$ \\
\hline Graduate & $13(12.9 \%)$ & $14(13.8 \%)$ \\
\hline Doctorate & $4(4.0 \%)$ & $2(2.0 \%)$ \\
\hline Marital Status & & \\
\hline Married & $96(95.0 \%)$ & $74(73.3 \%)$ \\
\hline Unmarried & $5(5.0 \%)$ & $24(23.8 \%)$ \\
\hline Others like widow/ divorcee & $0(0 \%)$ & $3(3.0 \%)$ \\
\hline Monthly Family Income (Rs.) & & $16(15.8 \%)$ \\
\hline$<30000$ & $8(7.9 \%)$ & $47(46.5 \%)$ \\
\hline $30000-60000$ & $47(46.5 \%)$ & $38(37.6 \%)$ \\
\hline$>60000$ & $46(45.5 \%)$ & $52(51.5 \%)$ \\
\hline Family Type & & $49(48.5 \%)$ \\
\hline Nuclear & $58(57.4 \%)$ & \\
\hline Joint & $43(42.6 \%)$ & \\
\hline
\end{tabular}

Table 2: Distribution of respondents according to their Knowledge about part of body affected in Cervical Cancer

\begin{tabular}{|l|c|c|}
\hline \multirow{2}{*}{ Body Part / Organ Involved } & $\begin{array}{c}\text { Government School } \\
\text { Teachers (N=101) }\end{array}$ & $\begin{array}{c}\text { Private School } \\
\text { Teachers(N=101) }\end{array}$ \\
\cline { 2 - 3 } & $\mathbf{n}(\mathbf{\%})$ & $\mathbf{n}(\%)$ \\
\hline Cervix & $23(22.8 \%)$ & $31(30.7 \%)$ \\
\hline Uterus & $35(34.7 \%)$ & $27(26.7 \%)$ \\
\hline Female cancer & $7(6.9 \%)$ & $2(2.0 \%)$ \\
\hline Lower abdomen & $4(4.0 \%)$ & $0(0.0 \%)$ \\
\hline Neck & $3(3.0 \%)$ & $6(5.9 \%)$ \\
\hline Vagina & $7(6.9 \%)$ & $16(15.8 \%)$ \\
\hline Don't know & $22(21.8 \%)$ & $19(18.8 \%)$ \\
\hline Total & 101 & 101 \\
\hline
\end{tabular}


Table 3: Distribution of respondents according their Knowledge about Risk Factors of Cervical Cancer

\begin{tabular}{|l|c|c|}
\hline Risk Factors (Multiple Responses to open ended Question) & $\begin{array}{c}\text { Government } \\
\text { (N=101) }\end{array}$ & $\begin{array}{c}\text { Private } \\
\text { (N=101) }\end{array}$ \\
\hline Infection & 11 & 6 \\
\hline Poor hygiene & 7 & 1 \\
\hline Smoking & 5 & 1 \\
\hline Unsafe Sex & 4 & 7 \\
\hline Oral contraceptives & 3 & 1 \\
\hline Multiple Pregnancy & 2 & 3 \\
\hline Don't know & 79 & 79 \\
\hline Myths like Infertility, Use of sanitary pads are risk factors & 8 & 8 \\
\hline
\end{tabular}

Table 4: Distribution of respondents according to their knowledge about Signs and Symptoms of Cervical Cancer

\begin{tabular}{|l|c|c|}
\hline \multicolumn{1}{|c|}{ Signs and Symptoms* } & $\begin{array}{c}\text { Government } \\
\text { School Teachers } \\
\text { (N=101) }\end{array}$ & $\begin{array}{c}\text { Private School } \\
\text { Teachers } \\
\text { (N=101) }\end{array}$ \\
\hline Heavy Bleeding During Periods & 18 & 14 \\
\hline Discharge From Vagina & 11 & 13 \\
\hline Lower Abdominal Pain & 13 & 11 \\
\hline Pain In Legs & 1 & 8 \\
\hline Back Pain & 1 & 7 \\
\hline Bleeding Between Periods & 0 & 7 \\
\hline Irregular Menses & 8 & 6 \\
\hline Pain And Bleeding During Intercourse & 7 & 6 \\
\hline Bleeding After Menopause & 3 & 3 \\
\hline Weight Loss & 5 & 2 \\
\hline Don't Know & 63 & 63 \\
\hline
\end{tabular}

*Multiple responses were allowed

46.5\% in Private) and are having nuclear type of family (57.4\% in Government and $51.5 \%$ in Private).Majority of respondents were aware that Cervical Cancer is a Non Communicable Disease (91.1\% in Government and 88.1\% in Private) and cannot spread from contact with patient.

Table 2 shows that only $22.8 \%$ teachers of
Government schools were aware that Cervical Cancer involves cervix part of uterus and in Private school teachers this awareness was slightly more as $30.7 \%$ gave this answer.34.7\% of Government Teachers and $25.7 \%$ of Private Teachers were aware that it involves uterus but not sure about which part of uterus it involves.6.9\% of Government Teachers and $2 \%$ of Private Teachers thought it as female 
reproductive organs but unaware of exact part involved.3\% of Government teachers and 5.9\% of Private teachers confused it with cervical part of spine (neck). $21.8 \%$ of Government Teachers and $18.8 \%$ Private Teachers responded that they are unaware about it.

Around 79 respondents were totally unaware about the risk factors for cervical cancer Other respondents' knowledge was also poor as most of them gave either one or two correct responses. Some Myths like Infertility, Heredity, Use of sanitary pads and depression as Risk factors also recorded in data.(Table 3)

As shown in Table 4, total 63 respondents were totally unaware about signs and symptoms of Cervical Cancer in both Government and Private Schools. As question was open ended in nature usually one or two correct responses were recorded by respondents which shows a very poor knowledge of signs and symptoms in study community.

Only 23.8\% of Government School Teachers and $37.6 \%$ of Private School Teachers were aware that Infection of HPV increases risk of Cervical Cancer. Majority of respondents mentioned their source of information is mass or social media $37.6 \%$ in Government and $43.6 \%$ in Private) which shows popularity of mass and social media, others were family or friends and print media. Majority of teachers (92\%) think creating awareness about cervical cancer in adolescent girls will be useful. Around 86\% School Teachers were in favor of adding this knowledge in school curriculum.

\section{Discussion:}

In present study it was found that, $22.8 \%$ teachers of Government schools were aware about Cervical Cancer and in Private school teachers this awareness level was slightly more (30.7\%).

Mihaela et al (2017) ${ }^{[7]}$ has done study in Romanian women which shows very high awareness 95\%. Toye (2017) ${ }^{[8]}$ et al did study among female public secondary school teachers in Mushin local government area of Lagos State, Nigeria. They reported very high $(100 \%)$ awareness. Similarly Touch et al (2016) ${ }^{[9]}$ conducted study among Cambodian women in Kampong Speu Province reported awareness of $74 \%$. All foreign studies showed high awareness levels than present study, it may be due to more strong public awareness programs in these countries.

In present study, $79 \%$ respondents were unaware about risk factors and 63\% respondents were unaware about signs and symptoms of cervical cancer whereas in Salem M et al (2017) ${ }^{[10]}$ study conducted in Saudi female secondary school teachers in Al Hassa, Saudi Arabia shows 65.4\% and 63.4\% were less-knowledgeable about Cervical Cancer risk factors and early signs and symptoms, respectively. Present study showed low level of awareness than Salem M et al (2017) ${ }^{[10]}$ study, reason may be that present study involves middle, high and secondary school teachers whereas study involved only female secondary school teachers.

In the study, 79\% respondents are unaware about risk factors and 63\% are unaware about signs and symptoms whereas Jain S M et al $(2016)^{[11]}$ study in a Tertiary Care Institute in Central India (MGIMS Sewagram Maharashtra) reported $42.3 \%$ respondents were not aware of any risk factor and $27.6 \%$ were not aware of any symptom of cancer cervix. Jain S M et al $(2016)^{[11]}$ study reports high awareness levels because it involved nurses who are from paramedical background where as our respondents were teachers and from non-medical background which shows educational background also plays major role in awareness.

In present study majority of respondents said their source of information is mass or social media (37.6\% in Government and $43.6 \%$ in Private) and family \& friends $30.7 \%$ in Government and $38.6 \%$ in Private) whereas Narayana G et al (2017) ${ }^{[13]}$ study reported that most of (74.6\%) the respondents had heard about cervical cancer and majority of them are heard from media (41.6\%) and friends (20.5\%). In our study information from friends was reported higher which shows people discuss health issues 
with near and dear ones which may be due to good educational status of respondents.

\section{Conclusion and Recommendations:}

Study shows that awareness of Cervical Cancer'srisk factors, signs and symptoms is low in even educated class like school teachers of a modern progressive city like Chandigarh. Awareness can help in reducing risk and early detection of Cervical Cancer is an established fact. School Teachers are important stake holders of society and influencer on their students so it is recommended that special trainings and awareness activities for cancer including cervical cancer should be conducted for influential stake holders like school teachers.

\section{Limitations:}

The major limitations of study were: collected data was based on self- reporting due to constraint of time,due to lack of time interview method cannot be applied which may be a better approach and as study was conducted in specialized group so findings cannot be generalized for entire population.

\section{Declaration:}

Funding: Nil

\section{Conflict of Interest: Nil}

\section{References:}

1. Bruni L, Barrionuevo-Rosas L, Albero G, Serrano B, Mena M, Gómez D et al S.ICO/IARC Information Centre on HPV and Cancer (HPV Information Centre). Human Papillomavirus and Related Diseases in India. Summary Report 27 July 2017. [Date Accessed on 26/4/2018 from http://www.hpvcentre.net/ datastatistics/reports/IND.pdf ]

2. ICMR Report 2016; icmr.nic.in/icmrsql/archive/2016 Date Accessed on 26/4/2018

3. Bosch F, Manos M, Munoz N, Sherman M, Jansen A, Peto J et al. Prevalence of Human Papillomavirus in Cervical Cancer: a Worldwide Perspective. JNatCan Institute. 1995;87(11):796802.

4. Kaarthigeyan K. Cervical cancer in India and HPV vaccination. Ind J Med Paediatr Oncol,2012;33(1):7-12.

5. Shaw W, Shaw W ,Padubidri V, Howkins J , Bourne G.Shaw's textbook of gynaecology. 16thed. New Delhi :Reed Elsevier India Private Limited,2015: 485-501

6. Cancer Burden in Chandigarh and Punjab State First year report: 2013 .Population Based Cancer Registries at Chandigarh and SAS Nagar, Sangrur, Mansa Districts Punjab State, India
http://health.punjab.gov.in/sites/default/files/Punjab\%20PB CR\%20summary\%2023\%20Feb\%202016_0.pdfDate Accessed on $18 / 2 / 2021$

7. Mihaela G, Razvan Pi, Anda P, Ana M G, Mioara M, Dumitru G. Perception and use of Pap smear screening among rural and urban women in Romania, Eur J Public Health, 2017; 27( 6), : 1084-1088

8. Toye MA, Okunade KS, Roberts AA, Salako O, Oridota ES, Onajole AT. Knowledge, perceptions and practice of cervical cancer prevention among female public secondary school teachers in Mushin local government area of Lagos State, Nigeria. The Pan African Med J. 2017;28:221

9. Touch S, Oh J-K. Knowledge, attitudes, and practices toward cervical cancer prevention among women in Kampong Speu Province, Cambodia. BMC Cancer. 2018;18:294.

10. Salem, M., Amin, T., Alhulaybi, A., Sami Althafar, A., Abdelhai, R. Perceived Risk of Cervical Cancer and Barriers to Screening among Secondary School Female Teachers in Al Hassa, Saudi Arabia. Asian PacJ Can Prevention, 2017; 18(4): 969-979.

11. Jain SM, Bagde MN, BagdeND. ,Awareness of cervical cancer and Pap smear among nursing staff at a rural tertiary care hospital in Central India. Ind J Can 2016;53:63-6.

12. Narayana G., Suchitra M, Sunanda G, Ramaiah J, Kumar B, Veerabhadrappa K. Knowledge, attitude and practice toward cervical canceramong women attending Obstetrics and Gynecology Department: A cross-sectional, hospital based surveyin South India. Ind J Can, 2017; 54(2): 481-487 